\title{
Variations on an old Theme: Maternity for Women with a Very Successful Professional Career
}

\author{
Maria Lúcia Rocha-Coutinho \\ Universidade Federal do Rio de Janeiro/UNIVERSO (Brazil)
}

\begin{abstract}
In this study, relationships of middle-class women from Rio de Janeiro with their family and work are presented. A series of events during the $20^{\text {th }}$ century have changed woman's identity, previously centered on the roles of mother and wife, so that, there are now other options for women. Carioca girls are currently educated to compete, seek greater professional growth, and value their independence. However, some social discourses still reinforce women's former role the in the family. The notion that the mother-child unit is basic, universal, and, psychologically, the most appropriate, both for the child's healthy development and the mother's wholeness, is still firmly rooted. Motherhood is therefore one of the most complex and problematic matters for modern Carioca woman. Fifteen women with successful professional careers, residents of the city of Rio de Janeiro, varying in age from 30 to 40, and with children from 6 months to 3 years of age, were interviewed. The interviews had an invisible structure, were recorded and transcribed. The discourse of the resultant texts was analyzed, using the categories I established. In this project, I focus on the results of the analysis of the category "View of Maternity" of the interviewed women.
\end{abstract}

Keywords: woman, discourse, identity, maternity

En este estudio, se presentan las relaciones de las mujeres de clase media de Rió de Janeiro con sus familias y trabajos. Una serie de eventos del S. XX ha cambiado la identidad de las mujeres, previamente centrada en los roles de madre y esposa, de tal forma que hoy día hay otras opciones para ellas. Las chicas Carioca se educan para competir, buscar mayor desarrollo profesional y valorar su independencia. Sin embargo, algunos discursos sociales siguen reforzando su papel anterior en la familia. La noción de la unidad madre-niño como básica, universal y psicológicamente la más apropiada, tanto para el desarrollo sano del niño como para la integridad de la madre, sigue firmemente enraizada. Debido a ello, la maternidad es uno de los asuntos más complejos y problemáticos para la mujer Carioca moderna. Se entrevistaron a 15 mujeres con carrera profesional, residentes de la ciudad de Río de Janeiro, con niños de edades entre los 6 meses y los 3 años. Las entrevistas tenían una estructura invisible, se grabaron y transcribieron. El discurso de los textos resultantes se analizó, empleando las categorías establecidas. En este proyecto, me centro en los resultados del análisis de la categoría "Visión de la Maternidad" de las mujeres entrevistadas.

Palabras clave: mujer, discurso, identidad, maternidad

Correspondence concerning this article should be addressed to Maria Lúcia Rocha-Coutinho, Rua Eng. Cortes Sigaud, 187 apt. 401 - Leblon, Rio de Janeiro, RJ 22450-150 (Brazil). Phone: 55-21-2294 9452. Fax: 55-21-2294 0338. E-mail: mlrochac@imagelink.com.br 
Although the social discourse apparently describes the ideal marriage as that in which the husband, as much as the wife, invest in their professional careers and share responsibility for caring for and raising the children and household responsibilities ${ }^{1}$, studies we have developed with Carioca women $^{2}$ (Rocha-Coutinho, 2000, 2003a, 2003b), as well as projects completed in other parts of Brazil with men and women of various social classes (Araújo \& Scalon, 2005; Bruschini, 1990; Féres-Carneiro, 2003, 2005; Goldenberg, 2001, 1991; Jablonski, 1999; Negreiros \& Feres-Carneiro, 2004; Pacheco, 2005; Perlin \& Diniz, 2005; Possati \& Dias, 2002; Rocha, 2000; Strey, 1997; Wagner, 2002; Vaitsman, 2001) and in other countries (Elvin-Novak \& Thomsson, 2001; Harris, 1979; Hoffnung, 1992, 1995) continue to indicate to the fact that men as well as women, at various levels of consciousness, still appear to believe that the home and children are the wife's responsibility, whereas financial support for the family falls to the man. The woman's responsibility for the care of the children is wedged in the old idea that "mom is mom," that she is the most capable person to care for the children ${ }^{3}$ and which, in the ultimate analysis, identifies maternity with femininity. This position is largely reinforced by the inscription of maternity in the female body.

Maternity, above all, was not always seen in this way. The glorification of maternity and exaggeration of the responsibilities attributed to the mother are relatively recent, having been intensely reinforced in the XVIII and XIX centuries (Ariès, 1986; Badinter, 1981; Bauer, 2001; Harris, 1979; Rocha-Coutinho, 1994; Shorter, 1975). Before this, the raising of children was integrated with other tasks belonging to women, and was not even considered one of their main tasks. The necessity for survival in the preindustrial economy required, not only of men, but also of women, that production work be prioritized over reproductive matters. Women and men worked, thus, side by side, both inside and outside of the home. It was only with the growth of industrialization in society that public and private spaces began to be demarcated, that patriarchal power grew and that the work of the woman in the home, revolving basically around reproduction, became less valued (Burke, 1991; Carvalho, 1997; Duby \& Perrot, 1991).
Life in the modern, industrial society was characterized by a series of opposed pairs, including ideas about productive activity, such as home/work, work/leisure, production/reproduction, among others. Work has its place outside the home, in the public arena, is remunerated, valued, and carried out principally by men. At home, on the contrary, the private domain, is the family refuge, and work therein, basically carried out by women, is not paid work, since it is, supposedly, done "for love" and is not valued. To men, thus, has been passed the task of financial support, and to women, domestic tasks and child-rearing.

The transition of the feudal family for the modern, bourgeois family, was particularly ample, not attending only to the history of daily life. (Bauer, 2001; Del Priore, 2004; Habermas, 1971). On the contrary, it indicated key-traces that go to relations of production and constitution of subjectivities, in which are accentuated intimacy, individuality, and personal identity. On the contrary, it was only with the advent of industrial society that the theme of individuality, with emphasis on subjectivity and personal identity, began to develop and that the public and private domains were separated, their territories, as much as their significance, being restructuring (Giddens, 1990, 1992; Machado, 2001; Peixoto, Singly \& Crechelli, 2000; Schnitman, 1996). Then, a radical change came about in life priorities, and free-will and the search for personal happiness came to be emphasized.

In this new familial reality, based in affection among its members, in the greater intimacy between husband and wife and between parents and children, the family became centered in the wife-mother figure. She came to be mainly responsible for the well-being of the children and the husband, and became an important intermediary between the father, ever more absent due to work outside the home, and the children. The combination of housework and childcare constituted "full-time work" for the mother, but did not bring any economic benefits that were connected to work outside the home (Duran, 1978). This fact resulted, for the woman, in economic dependence on her husband, the financial provider of the family, and in a psychological dependence on her children, as products of her motherhood ${ }^{4}$.

1 Although, in the Brazilian case, this ideal is not verified in practice in all middle and upperclass homes, much less, in the common home, the social discourse in our country still is very stuck in the idealization of this bourgeois model, which seems to pervade all the social classes, including low income where the dailyexperience is very distant from it, as observed for Pacheco (2005) in his doctorate dissertation on poor women, heads of household, living in the favelas (slums) of the city of Rio De Janeiro.

2 The word "carioca" refers to persons born and/or living in the city of Rio de Janeiro.

3 Speaking on this matter, in his book Dubious Maternal Affection, Berg (1972) confirms the basis for development of these oldfashioned ideals around the importance of the mother for the proper development of the child: "The experts have no doubts: they are unanimous in their statement that only the mother, and no one else, should take care of her child. No other question is answered so definitely and plainly. The mother is the oersis to look after her child" (pp. 10-11). For more in respect to the development of these ideas, see Badinter (1985).

4 Child-care, itself, can be performed as much by men as by women, being differentiated, therefore, from maternity, which is biologically connected to the woman. 
In the process of "naturalization" of these feminine functions, a series of characteristics began to be demarcated, such as, for example, sacrifice, docility, among others, almost all of which were tied to the necessary characteristics to be a "good" mother, bringing them to be identified with maternity and femininity, which, in various degrees, remains to this day. Thus it is that the definition of the feminine identity, for a long time, encouraged a massive discrimination against women, as any socially valued abilities in women were negated, thus guaranteeing, for a long time, the primacy of men in public life.

Identities, however, are not fixed, immutable entities, but, first, they are historical discourses and culturally situated constructions (Hall, 1987; Ortiz, 1985; Rocha-Coutinho, 1994, 2000). Any identity, whether sexual, racial or ethnic, is always an abstract entity, although, in a certain form, indispensable as a point of reference. It is a discursive construction that transcends the particularities of individuals and the restricted groups by inserting them into a total and globalizing project, in concert with the anxieties and myths of a particular society at a specific historical time.

A series of changes occurring throughout the 20th century, many occurring through various social movements, principally that of the feminists, that then were developed in distinct locations and times, questioned the old dialog surrounding feminine identity, bringing new discourse that began to alter it, making new choices available to women. We would like to emphasize, above all, that the totally unified, complete, secure and coherent identity was always, and continues to be, a "fantasy", a discursive construction.

In contemporary societies, the constant and rapid changes, the systems of signification and cultural representation are multiplied, becoming, as Hall (1987) indicated, this illusion of an even more difficult unified identity. As this author confirms, we, actual subjects, are "confronted by a disconcerting and changing multiplicity of possible identities, with each one of which we may identify ourselves - at least temporarily" (Hall, 1987, in Portuguese translation: p. 14). Identity has become, in this way, in today's world, a "mobile celebration", or, it is "formed and transformed continuously in relation to the forms by which we are represented or interpolated in our cultural systems that surround us" (Hall, 1987, in Portuguese translation: p. 13).

In this way, the subject, that previously lived the false illusion of a unified and stable identity, is now living deeply, and much of the time unconsciously, a fragmented identity, which is composed not of one unique identity, but of various identities, sometimes contradictory and unresolved. It is thus that, with the carioca women with whom we come to work (Rocha-Coutinho, 1998, 2000), the modernizing social discourse, which exalts equality of rights and duties between the sexes, coexists, in its discourses, with the old disparities in relation to social roles exercised by men and women.

One of the ways encountered for these women to reconcile the old discourse about femininity with the more modern and current discourse was to situate the questions in terms of "personal choices". That is, individuals no longer need to submit themselves to pre-established roles. They have freedom to choose how they wish to live their lives, doing that which they believe to best for themselves. People can, thus, choose to repeat the "old", previous discourse, as much as to opt for the "modern". But, almost always, the choice went for a compromise, an attempt to reconcile the two. Or, that is, a discourse on "choice" ended up situating the woman between possibilities that cause impasses that are not perceived by her as such.

It seems, therefore, that new attributes and behaviors are being seen by women no only as possible, but also as desirable. However, its acceptance still stumbles over our old defining discourse on feminine and masculine identities, resulting in the coexistence of contradictory, and often conflicting, discourses ${ }^{5}$. Today's woman must be multiple: a competent professional, cultured, intelligent, a good housekeeper, a zealous and present mother, without neglecting her appearance and investing in her sensuality.

We believe, thus, that the social discourses, that configure current female identities, do not substitute the old feminine identity, but, initially, simply amplified it to incorporate this new role of interested and competent professional. This fact, as we see it, has important consequences for the animation of today's woman, as much at home as in the professional arena.

Among the changes occurring in recent decades, it is fitting to mention some important technological developments in the bio-medical field, such as the rise of the contraceptive pill, which made contraception relatively secure, effective, and available for the majority of women in the 20th century, dissociating sexuality from procreation. With this, the number of children in developed nations and in the higher social classes of developing nations, including Brazil, decreased ${ }^{6}$.

This decrease in the number of children for women reflects, however, not only the efficacy and availability of

\footnotetext{
5 Figueira (1986) used the term "unmapping" to designate this coexistence of "varied and contradictory maps inscribed in various and relatively dissociated levels within the subject" (pp. 22-23).

6 In the case of Brazil, one sees in the data published from the last IBGE (Instituto Brasileiro de Geografia e Estatística/Brazilian Institute of Geography and Statistics) census completed in Brazil that a decrease is indicated, throughout the country in general, and in the city of Rio de Janeiro, in particular, in birth rates.
} 
contraceptive methods, but also an improvement in education and a perception, on the part of a growing number of women, that life can provide other emotionally gratifying experiences beyond maternity. As Lott (1981) indicates,

Decreased fertility rates are a consequence of increased educational and occupational aspirations and pressures by women. To regulate her reproductive life, a woman must also come to believe that it is morally right to control her own body, and she must acquire knowledge regarding how best and most safely to do so (p. 213).

The increase in educational and occupational opportunities is the result of political and economical changes. and, in Brazil, in particular, they distinctly affect the various social classes. In what is said of the middle and upper classes in our country, we can confirm that, although some gender differences persist, including in the educational context, girls today are educated, as are boys, to compete and seek ever increasing professional development, to believe in their abilities and to fight for personal success, initially in school, and, afterwards, in the professional arena, and to value their independence. Thus, in spite of the persistence of some forms of discrimination in the professional world, these women are increasingly assigning greater importance to their professional careers. Certainly, mechanisms of discrimination against women in the public domain still persist, although they are ever more subtle today (Hirata \& Maruani, 2003; Rocha, 2000). However, every day, Brazilian women open more space and fill positions of greater power and status in business.

At the same time, various social discourses continue to reinforce their role in the family as wives, and, principally, as mothers. Their socialization continues to encourage development of characteristics essential to their role in the family, which can be seen, for instance, in the persistence of certain feminine games, such as playing house, among others, engendering the development of a sense of interdependence in relation to people, and the sense that the activity of caring for the necessities of others becomes nearly vital for their well-being 7 . It seems, thus, that "the current notion in the 21 st century that "the woman's place is in the home" persists, having been altered, only, to "the essential place of the woman is in her home,", as Hoffnung indicates (1995, p. 164).
It is our opinion, thus, that, in respect to the contemporary woman, and especially in the upper and middle classes, one of the most complex, conflicting and problematic matters continues to be motherhood, and, especially how it fits in with her career or profession ${ }^{8}$. To a large extent, also, in spite of all the changes that have occurred in the last decades, it appears that our beliefs still are very tied to the idea that the mother-child unit is basic, universal and psychologically more appropriate, as much for the healthy development of the child, as for the completeness of the mother. In the words of Berg (1972),

The experts have no doubts: they are unanimous in their statement that only the mother, and no one else, should take care of her child. No other question is answered so definitely and plainly. The mother is the person to look after her child (9-10).

Once, as Hoffnung (1995) indicates, child-rearing is an extremely necessary social work, of fundamental importance for the continuity of societies themselves, gratifying for the human "instinct" to generate beings, beyond highly valued in the life of women that have children, it is easy for us to believe in these specialists and accept the "mystique of maternity". This it is that, as much for executive interview subjects in research that we just concluded (Rocha-Coutinho, 2003a, 2003b), as for university students interviewed in prior research (RochaCoutinho, 2000), maternity was viewed, by the majority of them, as the essence of the feminine condition ("female being" = "mother being"), and the mother was considered indispensable for the proper and healthy development of her children.

This vision of motherhood appears to be verified in other countries, as well, with strong social policies that aim for equality between the sexes, as is the case in Sweden. In research conducted by Elvin-Nowak \& Thomsson (2001) with Swedish mothers, the authors concluded that:

Many studies have shown that the reality of motherhood for Swedish mothers means constantly balancing caring for the child with working outside the home . . According to what has been learned in this study, this is the reality of daily life, based on parallel and competitive discursive positions. Together these discourses form a positive femininity which prioritizes motherhood but also requires a certain orientation toward the world outside the child (p. 27).

\footnotetext{
7 This fact can be observed in the discourse of executives that we studied in a previous project (Rocha-Coutinho, 2003a, 2003b). Upon pointing out the difference in feminine and masculine forms of work, our interview subjects indicated, among other things, the women are generally more careful, tactful and attentive in dealing with other team members, these attributes being traces of the old feminine identity.

8 We believe that this problem becomes more complex, problematic, and conflicting, in the case of Brazilian women in the middle and upper classes. This is because, despite the fact that, at this current time, in order to attend to the financial necessities of the majority of families, it has become necessary, in general, that both partners have paid work (to this respect, in reference to America families, see Gerstel \& Gross, 1995), which has brought many middle class Brazilian women into the workforce, the question may still be configured, to a certain point, for them as a "choice". In the case of women in the lower classes, however, work outside the home was never presented as an option, since they have practically always had to work to sustain and/or compliment the family income. Often it is they who sustain their families (see Pacheco, 2005).
} 
In this study, the authors also emphasize the fact that the current social policy in the country and that encourages equality among the sexes in other sectors of society coexists with the dominant discourse on the child, and, consequently, on the mother, and thta it is strongly influenced by psychological development theories that accentuate the necessity that mothers be accessible and close to their children. These ideas, founded in theories about primary infancy, as the psychoanalytical postulates of Winnicott and Deutsch (in Badinter, 1981) or or Bowlby's theory of attachment (Bowlby, 1969)9, were, later, appropriated, sometimes in a distorted and badly interpreted manner, by the social discourse to also include the relationship between mothers and older children, including adolescents.

It can be observed, thus, that, even in countries with advanced social policies of gender, such as Sweden, old standards for motherhood coexist, in the social discourse, with new ideas about the necessity for the woman to invest in a professional career, and around equality of roles between men and women. Motherhood, understood in the old sense, comes into conflict with the other important aspects of the woman's life, such as effective investments in a professional career, causing women to seek a means of compromise, not always fully reached, in order to try to reconcile these two "priorities" in her life, her family and her career.

It seems, as Hall (1987) confirms, that in contemporary societies, with constant and rapid changes, the systems of cultural significance and representation are multiplied, rendering even the illusion of a unified identity very difficult. The current subjects of this study are deeply living, and often in an unconscious way, a fragmented identity, a "mobile celebration" in the words of Hall, that is, an identity composed not of one unique, but various, sometimes contradictory and unresolved, identities. It is thus, that, in the discourse on women, both Brazilian and Swedish, or other corners of the Western World, the modern social discourse, that exalts equality of rights and duties between the sexes, coexists, side by side, with old disparities in relation to the social roles of men and women, some of which are very difficult to eradicate, since they are reinforced by biological differences between the sexes, as in the case of maternity.

We believe in this way that one of the big challenges of the current, middle class Carioca woman that we've come to study, it still connected to the question of the "double day" of work. To reconcile with the level of excellence that executives that we studied (Rocha-Coutinho, 2003a, 2003b) demand of themselves in both spheres of activity, home and work, as they pointed out, domestic tasks, the education of their children, and, even, to worry about professional activities and good performance at work is disadvantageous for the personal and career plan of any person. It is our opinion that, in order to effectively alter this disadvantageous condition of the middle class in Brazilian society, a better comprehension of the limiting effect of maternity on the participation of these women in the public sphere is necessary, as well as the solutions that have been opened and sought by them to better deal with the matter.

In the search for equality, it seems insufficient for these middle class carioca women to perform their work as well as men. We believe that, while society, and this woman herself, do not relativize the role of mother, and while childcare is not considered sufficiently important to be performed as much by men as by women, the responsibilities and special benefits of maternity will continue placing this woman in second place in public life.

A great contemporary problem for them, however, appears to consist, largely, in how to fit motherhood into their lives, without abdicating other activities and/or restricting their ambitions. Women, in general, have many reasons to want to have children; they like children, they want to experience pregnancy and birth, construct a family like their family of origin, and, conform to social expectations, among others. The liberation of middle class women indicated, partly, liberation from the obligation to perform the role that was attributed to her by society, which is, to be free to be able to make choices, including opting to be a mother or not. However, the self-satisfaction, for the majority of contemporary, middle class Brazilian women, still includes motherhood and a romantically/sexually gratifying relationship, beyond a successful professional career. Motherhood in the old form, in which it is still structured in Brazilian society (Del Priore, 2004), however, is very limiting for the woman, and often implies a rearrangement of the woman's professional objectives. In this text we present part of the results of research that we developed with middle class Carioca women with a successful professional career, and small children, in order to better understand this question.

\section{Method}

\section{Participants}

We interviewed 15 highly successful professional women, meaning, with a good financial return and high degree of satisfaction at work and investment in their careers, residents of the city of Rio de Janeiro, ranging in age from 30 to 40, and with children ranging in age from 6 months to 3 years. The interview subjects were selected in contact that we established with businesses and investment banks in Rio de Janeiro.

Our objective was, among other things, to better understand, through an analysis of their discourses, what was their sense of maternity, how they fit/are fitting maternity into their lifes, what ways and solutions were sought and found by them to better exercise their functions as mother, how they tried to reconcile motherhood with their professional career and what concessions they were open to making/had made in one or more area of their lives to better deal with this dual role. 
We chose to interview women with successful professional careers, and with small children, that, by requiring extensive attention and care, can constitute a complication in the attempt to reconcile home and work, bringing about a possible rearrangement of their professional objectives that could include not only postponement of the investment in their career, even to abandoning their professional careers, even if temporarily, to be better able to invest in motherhood ${ }^{9}$.

\section{Procedure}

The interviews had an invisible structure9 and the women were interviewed separately, at times and places convenient for them. It is fitting to reiterate here that the questions asked by of the subjects included not only the way in which they, themselves, saw or felt about the matters in question, but, also the way they believed women in general saw or felt about about them. This is because our own recent research on the topic (in Rocha-Coutinho, 2001), has pointed to the fact that cognitive and social factors can hinder members of a socially "disadvantaged" group, such as women are, from recognizing and/or being conscious of the inequality to which they are personally subjected, even when they are aware of discrimination suffered by the group to which they belong.

All of the interviews were recorded and completely transcribed, preserving, in the most faithful manner possible, what was said (with grammatical errors, use of colloquial expressions, slang and profanity, pauses, hesitation and emphasis, among other things). Furthermore, whenever important for our objectives, comments on what occurred in the interview situations were inserted, such as smiles, coughs, nervousness in the speech, exaggerated gesticulations, among others.

\section{Data Analysis}

Upon completion of the transcription of the interviews, the resultant texts were submitted to an analysis of the discourse from categories, largely, resulting from the very words of the interview subjects. By this, we mean to say that, despite having certain questions in mind to be observed, the interpretive categories used emerged mainly from the texts of the interviewees themselves, which means, from the transcriptions of the interviews, which became clearer the more the discourse analyst heard and read repeated elements (for more information, see Rocha-Coutinho, 1998).

This way of establishing the categories is connected to our basic posture in discourse analysis that sees the text always as the central part of any analysis, and, thus, any interpretation is, largely, limited by it. In this way, regardless of of the fact that our interpretation may be, without doubt, influenced and directed by our own theoretical positions and ideologies, we seek to read and analyze the discourse within, from the significance encoded in the very words, and only then going beyond them. Thus, in our analysis, we attempt to infer, from the interview subjects discourses, behaviors expected and/or wanted of them, and the ideological systems adjacent to these behaviors (see RochaCoutinho, 1998).

As far as the use of open interviews and discourse analysis, we believe that the use of oral histories, whether in the form of life stories or in the form of interviews that seem like a conversation, like those that we are using, as well as the use of discourse analysis in place of a content analysis (Bardin, 1977) to interpret the resulting texts, are especially useful in studies about women. If we want to better understand how the dominant ideologies, reflected and reinforced by various types of discourse, structure our institutions and mold the daily lives of people, it is necessary to hear not only that which what real people say about their concrete lives, but also how they do it (Schiffrin, 1996).

Oral history presents itself as one of the best ways to have people speak of their lives, since it allows the researcher to explore the subjects' emotional experiences as much as the facts and activities of their lives. In speaking, people articulate their own experiences and reflect on the significance of these experiences in themselves. In this way, we can obtain a broader picture of how the subjects see themselves in the work, of how and to what they attribute value, and the special significance they attribute to their actions and their place in the world.

This point has especially been shown to be important in gender studies ${ }^{10}$, especially of women, because, for them, the ability to value their own thoughts and experience is often hindered by doubts and hesitations when their personal experience doesn't agree with the myths and values about how a woman "should" behave and feel (Anderson, Armitage, Jack \& Witter, 1990. An analysis more attentive to the language and significance of important words they use to describe their experience allows better comprehension of how women are adapting to the culture in which they live. We believe, thus, that it is necessary to be beyond, exploring not only the significance of the words employed by our subjects, but also the very form of their speeches, if we want to take full account of this "duplicity" of the mind of our current women subjects (Anderson, Armitage, Jack \& Witter, 1990; Rocha-Coutinho, 2000).

\footnotetext{
9 Winnicott (in Badinter, 1985), for example, confirmed that health, physical and psychological, of the adult was wormed during infancy and was established by the mother, but, especially during the first weeks and months of the child's existence.

10 For a more complete discussion on this matter, see Badinter, 1985; Preto (1988); among others.
} 


\section{Results}

In this text, we are going to concentrate on the relative results of the analysis of one of our categories, "Vision of Maternity", making mention, in our conclusion, of some aspects referring to the other two categories of analysis, "Vision of Paternity" and "Career-Family Reconciliation".

In respect to what is said about the ideal time to be a mother, this is seen by the interview subjects as something very personal, that varies from woman to woman. In general, however, the majority of them indicate a good relationship with their partner, and professional and financial stability as important conditions for the arrival of a child:

An ideal time exists, I think so, first the couple has to be together for a some time, knowing each other or living together, and have passed the stage of physical infatuation without having a child, because it's another step, no? ... So, I think a time exists, sure ${ }^{11}$, that I think that, at last, beyond job stability, dough, to be alright, I think the couple has to have had a time to enjoy each other enough first. (C3).

Motherhood is perceived by all of the interview subjects as something very intense, the greatest love, the most important thing in the life of a woman:

To be a mother is a very intense thing (smile)...to be a mom, I think is all like that, it's the greatest love that you have ever felt like that for a person . . . It's a love beyond any other thing, you know? (C2).

Beyond this, for most of them, being a mother is, above all, a donation or sacrifice:

So, I think it's a lot like that, this thing, being a mom is a donation, for me really, you give of yourself. I believe this is being a mother (PZ1).

The love of a mother is that love that is self-sacrificing and that is, that you don't, you only want what's good, isn't it? (C1). In the speech of a good part of the interviewed subjects, even, it seems that the idea that there is a "maternal instinct", or something like it, in spite of not applying to all women and sometimes being seen as something that may or may not develop in a woman, is present in most of them:

for me, then, first, I think that this is a little of the maternal instinct. I think the person has to have this inside of her to be able to be a good mother, to be able to give of herself to a child, no? ... And, there are people that I see that have a child and treat the child badly or don't give it attention, and, I think that this is, comes from maternal instinct, you know? She doesn't develop this (C2).

It is interesting to note, here, that, even those that, in a first time, affirm that they don't believe in the existence of a "maternal instinct", shortly thereafter mention it, as can be seen in the speech below:
My mother is a psychoanalyst, and she always said that there isn't, that this doesn't exist, you know, but, I think that there is something that is as follows, we don't know how to care, don't know how to care, don't know how to care, but, when we love deeply, at the time we see, if we see our child suffer. Maybe this is the maternal instinct, you know? (C1).

For the interview subjects, the difference between being a mother now, and being a mother for in their mothers' time, is that the women of their mothers' generation didn't have any other major life goal beyond thinking of having a child, whereas, today, a woman has a career, a professional life, and, for this, some indicate that she must think well about the right time to have a child:

Motherhood...I think that, that in my mother's time it was...a little more...a little different, but I think sometimes it was easier, because it was motherhood, housekeeper, at least for my mother. . . But now (...) it's a little different, I work, ... I think that I work because I want to, and also, sometimes it's necessary, isn't it?, the money. But, you go to college, you want to study, then, sometimes... and you don't want to leave behind all of this to stay at home with the kids all day (F1).

It's fitting to point out, here, that the idea that work is very important for them and that they don't want to leave it all behind to stay with their children, as can be observed in the end of speech F1, arises, again, when the subjects are asked if they would be able to make any sacrifice for their children. Although all of them had answered this answer affirmatively, some of them, also, even thought about leaving work when they were on maternity leave, soon after said that this, however, would be a great sacrifice for them, something to be done in extreme cases, and, that, fortunately, their children are healthy, and will understand that their absence is going to be better for them in the future, and, thus, they don't need to take this extreme attitude:

We're already making enough sacrifices, I thin..., but, ...I even though, when I was on maternity leave, if I'm going to return to work, I'm not going, I'm going, I'm not going... and then I went back to work, if not...I think that, that I would even stay home...but for me it would be a great sacrifice, sure, to stay at home all day long, but, maybe I could do it, I don't know...there are a lot of factors. . children that need a lot of attention, ...there, yes ... and, I would stop working ... But this is not the case (laughs). They're healthy children... they don't need me all the time... The do need me, but, they'll understand that it's better for them, in the future, for their education (F1).

Even in respect to the differences between being a mother now and being a mother in their mothers' time, it

11 At this time, we are developing research with middle class carioca women who have abandoned, even if temporarily, their professional careers, in order to be able to dedicate themselves to their children. 
is important to note that the majority of the interviewed subjects state that, despite mothers of the previous generation being almost exclusively dedicated to their children, today's mother is much more present in their lives, participating in everything, and fully dedicating themselves to them when they are at home together, which was not always the case with their mothers. For our subjects, the quality of time that a mother spends with her children is much more important, too, than the quantity:

Certainly, today, yeah, I focus on quality, while in my mother's time, she focused on quantity, you know? She had to be with us the maximum time possible. Nowadays, since I don't have time, when I am with them, my time is just for them. My mother didn't do this. Like she had lots of time with us, sometimes she spent the whole day at home, and...she wasn't really with us. So, my weekends, the time when I am at home, I stay with them, I go out with them, take them to the movies, to the theater, these things $(\mathrm{C} 1)$.

Despite all of the changes, for our subjects, the mother is still seen as the personally mainly responsible for the children, putting the father in a secondary role, even because, according to them, the mother-child connection is much stronger than that with the father:

The connection to the mother is much stronger. . I see, but there is a difference, I think that, they are different love, but they are all necessary, understand? The present of a father has a different role, a figure, you know, I think that the father is much more a figure than the mother thing, of contact, of, of, of that gives food, that changes the clothes, that cares for the child, the mother is much more a matter of care, you know, of caring thus, a more tangible thing, while the father, I think, it more of a mythical thing, a thing more, more of a figure, you know, an example, and all, I think, and there I think that this tends to be differentiated. . The mother also she has her responsibilities even for her own development, her professional and personal success, but, and the greater responsibility to care for the child, I think that this thing of caring is much more maternal than paternal (PZ1).

Despite all of the subjects having indicated that the mother is more responsible for the children, and various of them having confirmed that the stronger relationship between the children and the mother is, largely, a product of the fact that the mother gives birth to the children, all of them said that, even though it falls a little more to them, that care of the children is well divided with their partners, as can be seen in speech PZ3, to follow:

But it is, it is well divided here at home, despite, to have this, they seek me out, but if [the father] is near, he grabs them, understand? If they both come to me, he grabs one, he plays he distracts the child and there they come to get used to being with him, too. It is, it falls a little more to us, but, in general, I, I say that it's well divided here at home.

For our subjects, the main change in their lives from motherhood is that everything comes to be centered in their children, to be more focused on meeting their needs, and, thus, their priorities changed. Beyond this, now they have a constant concern with the health and well-being of their children, which means, their head is always "connected" to them, which generates more responsibility and, also, more sacrifices:

When you have this, a child, your life comes to revolve around that other person, then, you stop being the most important person in your life, and the person you are raising becomes the most important. Then, mom, I think it's everything, isn't it? (PZ1).

Ah, it changed a lot, it changed a lot...you stay...your head stays always...connected to your child. . . creates more responsibility, doesn't it? Now really there are people that need me, my attention, my care...and also sustenance (F1).

Another change from mother, indicated by our subjects, was that, now, they have come to understand their mothers better:

I've come to understand my mother a lot more, since I've had a child, because it is, today I see, shit, how I made work for my mother, you know? (C3).

Work is seen by all of the subjects as something very important, an essential part of their lives, too, and, despite all of these problems, they confirm that they could not remain without work. However, the return to work after maternity leave comes with guilt and a constant concern for the wellbeing of the child, which brings them to be always "connected" to them. Thus, they supervise the children during the time where they are in the work, call home all day long to know of them, are always "inspecting" the house:

And when [the mother] is at work. . ., certainly always inspecting. I think that, in truth, the function of the working mother is more than an inspector (laughs), you're going to inspect your house, you're going to call, you're going to keep "hey, there, everything ok?", I don't know what (C3).

Despite everything, our subjects confirm that a greater sense of responsibility coming from motherhood positively affected their professional activities: now they are now more determined, more concerned with doing their jobs well, even because they fear a possible termination more. Beyond this, according to them, it also becomes more difficult to choose to change jobs, because, now they have someone that depends on them:

I have something, it's this, understand?, and I have a daughter, so I have to do my job very well, because I can't get fired, understand?, because, I have this daughter to feed. so, I think I improved [professionally]. You know? So, I think I have more determination to work (C1).

It's fitting to note, here, that all of our subjects live with a partner that also works. Most of them also confirm that they make less money than their partner. Thus, sustaining a child here appears to indicate being able to provide him/her with a better life (good schools, adequate medical care, extra courses, trips, vacations, among other things. Beyond this, it's necessary that they make a good salary to be able to maintain the support structure at home that the majority 
maintain (employee, nanny ${ }^{12}$, driver, etc) and that, often with the help of grandparents, mainly the maternal grandparents, allows them to be able to better exercise their professional activities.

As for the majority of the subjects, work is an important, even essential, part of their lives, according to them, to abandon their job would negatively affect their relations at home with their children, because they would not feel happy and complete, and would pass this dissatisfaction to their children:

and...I, I'm not, I don't see myself at home, and ... I don't see myself, I believe that ... I would harm, my, my ego, you know?, because I like, I'm a very active person, I like to work, I like this environment of business, of dealing with clients, which is my work in itself, so, if I was at home I would not have the opportunity to develop myself professionally, then I think that I would end up trapped, because I would be unsatisfied and this dissatisfaction would end up passing to the child (PS1).

The solutions indicated by most of the subjects to reconcile the two spheres of activity, despite being seen as individuals, involve separating the spaces of work and home, reducing the commute and overtime, and avoiding brining home work and worries:

Ah, yes, yes, certainly, [it is possible to reconcile a successful professional career and motherhood], but everyone has to find their own recipe, the formula to work it out, doesn't mean that the kind of life that I have, had, will be, will be a model for someone else (PZ3).

Principally, no?, not to bring any kind of annoyance, negative load or any such thing near to him [the child]. What belongs at work, stays at work. I get home, I enter another world. So they are distinct worlds, there is the mom world, and there is another world (PZ1).

Finally, it fits to add that PZ1, although finding it possible to reconcile a successful professional career with motherhood, makes an exception, affirming that it depends on what is understood as a successful career. For her, if a woman has bigger ambitions at work, that is, a desire to be an executive, it becomes quite difficult to reconcile career and motherhood:

Look...It depends a lot on what you mean by a successful professional career (laughs), doesn't it? I think it depends a lot on your ambitions. If you really want to be president of a company, really, you are going to have difficulties in, in motherhood, in being a mom, in your role as a mother, because nobody can be in two places at one, and the day has only twenty four hours, because the level of demands is very high, you know? so, I think that the the matter of having it clear with yourself is to have a real idea of what it is that you want in professional and personal terms, understand? Everything is a trade off. If you give a lot of emphasis to one or the other, really, you're not going to successfully compensate. so, if you're a person that really has ambitions...and...thus...a professional ambition, such that you're going to work fifteen, sixteen hours a day, you're not going to have time to be a mother, so I think that, I think, everything in moderation, so if you want to balance your personal life with your professional life, you have to really have, to see exactly what you really want, your ambitions, and be able to seek to reconcile.

\section{Discussion}

Our data point to the fact that maternity is perceived as something very intense, the greatest love, the most important thing in the life of a woman. The old idea of a "maternal instinct", still arises, even if sometimes in a confused and contradictory fashion, as something that doesn't develop in all women. Furthermore, it appears as though the idea remains that there is thing of the "flesh" in women, an extremely strong connection with the children that is formed during gestation. This, it is seen as "normal", that, especially in very small children, that they are "naturally" more connected to the mother. This relationship is, still, reinforced by breast-feeding, that can only be done by the mother. This vision of motherhood ends up also reinforcing the old idea that to be a mother, above all, means sacrifice and giving of oneself.

The strong connection to which our subjects refer between mother and child indicates that the differences between motherhood and fatherhood are, largely, attributed to a "nature" distinctly different between men and women. In this sense, although a rigid division of roles is already beginning to be questioned, the concept that "mother is mother" strongly persists, and, thus, she would be more responsible for the care of the children, while to the father fall, principally, the task of protector of the children and provider for their financial needs. Furthermore, it appears that the father's participation in childcare, especially in respect to family leisure time, is just now beginning to be seen as more common and with more involvement and pleasure on the part of the men.

Work appears to be an important, even essential element, in the life of these women. Reconciliation of a successful

12 By "invisible structure" we are referring to open interviews that, despite the topics approached, have been structured a priori by us, no written script was used and the order of emergence of the topics was determined by the flow of the conversation. Whenever necessary, also, the interviewer interrupted, requesting, for example, that the subject speak a little more on a specific topic or elaborate on something that they said, etc. In this sense, our interviewers seem more like a conversation in which the subjects "narrated" a little of their lives, doubts, anxieties, apprehensions and difficulties, among other things. 
professional career with motherhood is perceived by them not only as possible, but also as desirable, and the solutions sought out, the means of reconciliation, appear to be individual. We can say, however, that, most of the time, they manage to clearly separate the home/family and professional areas of their lives, reduce commutes and overtime, and avoid bringing work and work-related worries home, which is not always possible.

Contrary to what could appear at first glance, motherhood, by increasing the woman's responsibilities to provide a higher quality of life for the children, seems to improve and not hinder her performance at work, at least in the opinion of our subjects. In the end, as they confirm, now they can not give up work, because they have someone that depends upon them. As our subjects confirm, by having paid work, they can, together with their partners, provide not only a good quality of life (better schools, health care, extra courses, trips and vacations) for their children, as well as maintain the help structure (employees) that will allow them to continue to perform their professional activities in peace.

This point seems to confirm what we previously affirmed by noting that this doesn't seem to apply only to Brazilian cases, but, is a broader problem, seen throughout the world. In order to attend to the intense and growing financial demands of current families, it has become nearly imperative that, even in middle class homes, both partners contribute to the household budget, through paid work.

It seems, thus, that the greatest change in our subject's generation from that of their mothers is connected to the important of involvement of today's woman in work outside the home, which, sometimes, as we indicated int he previous paragraph, may not even be a "choice" freely made, even for women in the middle class, but, primarily, a necessity of these "new times", and the consequences thereof, principally the difficulty in attempting to reconcile this model of the traditional mother, that appears to still remain in their vision of motherhood, with that of the competent current professional that they say they wish to be. However, they lack time, a problem compensated for, as they themselves indicated, with the quality of the little time that they have to dedicate to their children. Contrary to their own mothers, who were nearly exclusively dedicated to their children, meaning, the were "full-time moms", but not necessarily present in their lives, that which appears important for the current mother is integral dedication at the times they are with their children, their effective participation in everything and in all important moments of their lives.

Finally, it is appropriate to add that our study included a limited number of middle class, carioca women, married, with small children, and that were dedicated to a professional career. Thus, we are sure that our data does not include all the possible ways of thinking and acting, as well as experiencing motherhood, with its satisfactions, difficulties and conflicts, many of which result from reconciliation of home and family with a successful professional career for the middle class Carioca women, much less, Brazilian women in general.

The current reality, as we indicate in our text, is multifaceted and includes an broad variety of though and behavior, that vary not only from person to person, but also for each one of us, not allowing us to speak, thus, of a model Brazilian woman, or even a model Carioca woman of the middle class, the population that we studied. However, we believe that our work could bring some contribution to a better comprehension of the situation of the woman of this social class in Brazil, as well as make possible a better dialog with studies that are being developed in other countries on the subject.

\section{References}

Anderson, K., Armitage, S., Jack, D., \& Wittner, J. (1990). Beginning where we are: Feminist methodology in oral history. In Joyce M. Nielsen (Ed.), Feminist research methods (pp. 94114). Boulder, CO: Westview Press.

Araújo, C., \& Scalon, C. (Eds.). (2005). Gender, family and work in Brazil. Rio de Janeiro: Fundação Getúlio Vargas.

Ariès, P. (1986). Social history of children and family. (Dora Flaksman, Trans.). Rio de Janeiro: Guanabara.

Badinter, E. (1981). The myth of motherhood: An historical view of the maternal instinct. Souvenir Press, London. [Translation: Waltensir Dutra, Um amor conquistado: o mito do amor materno. Rio de Janeiro: Nova Fronteira, 1985.]

Bardin, L. (1977). Análise de conteúdo. Lisbon: Edições 70.

Bauer, C. (2001). Breve história da mulher no mundo ocidental. São Paulo: Xamã/Edições Pulsar.

Berg, J. H. (1972). Dubious maternal affection. Pittsburgh, PA: Duquesne Univiversity Press.

Bowlby, J. (1969). Attachment. New York: Basic Books.

Bruschini, C. (1990). Mulher, casa e família: cotidiano nas camadas medias paulistanas. São Paulo: Fundação Carlos Chagas/Editora Revista dos Tribunais.

Burke, P. (Ed.). (1991). New perspectives on historical writing. Cambridge, UK: (Polity, [Translation: A escrita da história: novas perspectives. São Paulo: UNESP, 1992].

Carvalho, M.C.B. (Ed.). (1997). A família contemporânea em debate. São Paulo: Cortez.

Costa, A., \& Bruschini, C. (Eds.). (1992). Uma questão de gênero. São Paulo: Carlos Chagas Fundação Carlos Chagas/Editora Rosa dos Tempos.

Del Priore, M. (Ed.). (2004). História das mulheres no Brasil. São Paulo: Editora Contexto.

Duby, G., \& Perrot, M. (Eds.). (1991). A history of women in Western Europe. Glasgow: Harper \& Collins. [Translation: História das mulheres no ocidente. Porto, Portugal: Edições Afrontamento, vol. IV.]

Duran, M.A. (1978). El ama de casa: crítica política de la economía doméstica. Madrid: Zero. [Translation: A dona de 
casa. Yara C. Ferraro \& Wanda Capeller, Rio de Janeiro: Edições Graal, 1983]

Elvin-Novak, Y., \& Thomsson, H. (2001). Motherhood as idea and practice: A discursive understanding of employed mothers in Sweden. Gender and Society, 15, 407-428.

Féres-Carneiro, T. (Ed.). (2003). Family and couple: Contemporary arrangements and demands. Rio de Janeiro: Ed. PUC-Rio/São Paulo: Loyola.

Féres-Carneiro, T. (Ed.). (2005). Família e casal: arranjos e demandas contemporâneas. Rio de Janeiro: Ed. PUC-Rio.

Figueira, S. (1986). Uma nova família? Rio de Janeiro, RJ: Zahar Gerstel, N., \& Gross, H.E. (1995). Gender and families in the United States: The reality of economic dependence. In J. Freeman (Ed.), Women: A feminist perspective. Mountain View, CA: Mayfield.

Giddens, A. (1990). The consequences of modernity. Cambridge, UK: Polity Press. [Translation: As conseqüencias da modernidade. São Paulo: UNESP, 1991].

Giddens, A. (1992). The transformation of intimacy: Sexuality, love and eroticism in modern societies. Stanford, CA: Stanford University Press. [Translation: A transformação da intimidade: sexualidade, amor e erotismo nas sociedades modernas. São Paulo: UNESP.]

Goldenberg, M. (1991). Ser homem, ser mulher: dentro e fora do casamento. Rio de Janeiro: Revan.

Goldenberg, M. (2001). A invenção do casal. Estudos e Pesquisas em Psicologia, 1, 89-104.

Grossi, M.P., \& Pedro, J.M. (Eds.). (1998). Masculino, feminino, plural: gênero na interdisciplinaridade. Florianópolis: Editora Mulheres.

Habermas, J. (1971). The bourgeois family and institutionalization of a private sphere in reference to the public sphere. In M. Canevacci (Ed.), Dialética da família. São Paulo: Brasiliense.

Hall, S. (1987). Minimal selves. The real me, postmodernism and the question of identity. London, ICA Documents Program, 6, [Translation: T. S. Tomaz \& L.L. Guacira, Identidades culturais na pós-modernidade. Rio de Janeiro: DP\&A Editora, 1997.]

Harris, B. (1979). Careers, conflict, and children: The legacy of the cult of domesticity. In A. Roland \& B. Harris (Eds.), Career and motherhood: Struggles for a new identity. New York: Human Sciences Press.

Hirata, H., \& Maruani, M. (Eds.). (2003). As novas fronteiras da desigualdade: homens e mulheres no mercado de trabalho. São Paulo: Editora SENAC.

Hoffnung, M. (1992). What's mother to do? Conversations on work and family. Pasadena, CA: Trilogy Books.

Hoffnung, M. (1995). Motherhood: Contemporary conflict for women. In J. Freeman (Ed.), Women: A feminist perspective. Mountain View, CA: Mayfield.

Izquierdo, M. J. (1994): Uso y abuso del concepto género. In M. Villanova: Pensar las diferencias (pp.31-53). Barcelona: PPU.

Jablonski, B. (1999). Identidade masculine e o exercício da paternidade: de onde viemos e para onde vamos. In T. FéresCarneiro (Eds.), Casal e família: entre a tradição e a transformação (pp. 82-95). Rio de Janeiro: Nau Editora.
Lott, B. (1981). Becoming a woman. Springfield, Il: Charles C. Thomas.

Louro, G.L. (1997). Gênero, sexualidade e educação: uma perspective pós-estruturalista. Petrópolis, R.J.: Editora Vozes.

Machado, L.Z. (2001). Famílias e individualismo: tendencies contemporâneas no Brasil. Interface Comunicação, Saúde e Educação, 4, 11-26.

Negreiros, T.C., \& Féres-Carneiro, T. (2004). Masculino e feminine na família contemporânea. Estudos e Pesquisa em Psicologia, 4, 29-34.

Nicholson, L. (2000). Interpreting gender. Feminist Studies, 8, 35-43.

Ortiz, R. (1985). Cultura brasileira e identidade nacional. São Paulo: Brasiliense.

Pacheco, A.L.P.B. (2005). Mulheres pobres e chefes de família. Doctorate dissertation, Universidade Federal do Rio de Janeiro, Rio de Janeiro.

Peixoto, C., Singly, F., \& Cicarelli, V. (Eds.). (2000). Família e individualização do feminino. Rio de Janeiro: Fundação Getúlio Vargas.

Perlin, G., \& Diniz, G. (2005). Happy working couples: Myth or reality? Clinical Psychology, 17, 15-19.

Preto, N.G. (1988). Transformation of the family system in adolescence. In B. Carter \& M. McGoldrick (Eds.), The changing family life cycle: A framework for family therapy ( $2^{\text {nd }}$ ed.). NY: Gardner Press. [Translation: As mudanças no ciclo de vida familiar: uma estrutura para a terapia familiar (pp. 223-245). Porto Alegre: Artmed, 1995].

Rocha-Coutinho, M.L. (Ed.). (2000). Trabalho e gênero: mudanças, permanencies e desafios. São Paulo: Editora 34.

Rocha-Coutinho, M.L. (1994). Tecendo por trás dos panos. A mulher brasileira nas relações familiares. Rio de Janeiro: Ed. Rocco.

Rocha-Coutinho, M.L. (1998). A análise do discurso em psicologia: algumas questões, problemas e limites. In L. de Souza, M.F. Quintal de Freitas, \& M.M. P. Rodrigues (Eds.), Psicologia: reflexões (im)pertinentes. São Paulo: Casa do Psicólogo.

Rocha-Coutinho, M.L. (2001). Dos contos de fadas aos superheróis: mulheres e homens brasileiros reconfiguram identidades. Psicologia Clínica, 12, 65-82.

Rocha-Coutinho, M.L. (2003a). Quando o executivo é uma "dama": a mulher, a carreira e as relações familiares. In Terezinha Féres-Carneiro (Ed.). Família e casal: arranjos e demandas contemporâneas. Rio de Janeiro: Ed. PUC-Rio; São Paulo: Loyola.

Rocha-Coutinho, M.L. (2003b). Divididas e multiplicadas: a maternidade para mulheres executives cariocas. In Maria Inácia D’Ávila Neto \& Rosa Pedro (Eds.), Tecendo o desenvolvimento: saberes, gênero, ecologia social. Rio de Janeiro: MAUAD/Bapera Editora.

Saffioti, H.I.B. (1994). Posfácio: conceituando gênero. In H.I.B. Saffioti \& M. Munhoz-Vargas (Eds.), Mulher brasileira é assim (pp. 271-283). Rio de Janeiro: Rosa dos Tempos/Brasília: UNICEF.

Schiffrin, D. (1996). Narrative as self-portrait: Sociolinguistic constructions of identity. Language in Society, 25, 167-203. 
Schnitman, D.F. (1996). Novos paradigmas, cultura e subjetividade. Porto Alegre: Artes Médicas.

Scott, W.J. (1990). Gender: A useful category in historical analysis. Education and Reality, 16, 5-9.

Shorter, E. (1975). The making of modern family. New York: Basic Books. Stoller, R. (1985). Presentations of gender. New Haven, CT: Yale University Press. [Translation: Masculinidade e feminilidade: apresentações de gênero.Porto Alegre: Artes Médicas, 1993]

Strey, M.N. (Ed.). (1997). Mulher, estudos de gênero. São Leopoldo: Editora da UNISINOS.
Vaitsman, J. (2001). Gênero, identidade, casamento e família na sociedade contemporânea. In R.M. Muraro \& A.B. Puppin (Eds.). Mulher, gênero e sociedade (pp. 13-20). Rio de Janeiro: Relume Dumará.

Wagner, A. (Ed.). (2002). The family on stage: Traumas, dramas and transformations. Petrópolis, R. J.: Editora Vozes.

Received September, 11, 2006 Revision received January, 24, 2007 Accepted March, 15, 2007 